66 回回回回回回回回回回回回回回回回回回回回回 Випуск 32

УAK 347.124

Сабура Світлана Олександрівна,

аспірант кафеАри права інтелектуальної власності та корпоративного права

Національного університету "ОАеська юридична академія"

\title{
СПОСОБИ РЕАЛІЗАЦІЇ СУБ'ЄКТИВНОГО ПРАВА НА ТВОРЧІСТЬ
}

«Винаходити самому прекрасно, але те, що винайдено іншими, знати та цінити чи є меншим, ніж створювати"

й. Гете

Постановка проблеми. У наш час, у час розвитку великих можливостей прояву творчих зАібностей особистості, а також існування великої кількості варіантів та способів самовираження, важливим $€$ питання правового окреслення тих варіантів, які використовує Аюдина Аля реалізації своїх творчих зАібностей, аАже в подальшому творець матиме змогу захистити свої авторські права віА порушень. Ауже важливо окреслити ті варіанти Аій, які може використовувати автор піА час реалізації права на творчість (культурних прав), гарантованого Конституцією України.

Крім того, піА час створення об'єкта прав інтелектуальної власності особа може опинитися в ситуації, коли будуть порушені ії права, або вона може порушити права інших авторів. Тому визначення способів, завАяки яким громаАяни можуть заійснювати свої культурні права, а зокрема реалізовувати своє суб'єктивне право на творчість, Аопоможе уникнути також ситуацій, в яких автор ставить піА загрозу свої авторські права, та обійти стороною можливе порушенням прав інших авторів своїми Аіями.

В історії становлення авторського права питанню можливих способів реалізації суб'єктивного права на творчість приділялась невелика увага, що має результатом невелику кількість наукових робіт із Ааної теми. ААже визначені та викладені в наукових роботах думки великих правознавців минулих часів мають велику цінність Аля АосліАження та розкриття цієї теми.

Систематизація способів реалізації суб'єктивного права на творчість Аасть змогу в подальшому як іншим правознавцям піА час їхньої прак- тичної Аіяльності швиАко орієнтуватися в просторі юридичної інформації у процесі надання правових послуг, так і авторові під час реалізації свого суб'єктивного права на творчість ефективно захистити зазначені права.

Стан АосліАження теми. Питанню способів реалізації права на творчість, а також систематизації цих способів на виАи майже не приАіля^ось уваги з боку науковців-правознавців. Ауже часто поняття "спосіб" ототожнюється 3 поняттям "форма". Тим не менш, можна виділити авторів, АосліАження яких можуть бути піАгрунтям у розкритті цієї теми, а саме: О.С. Іоффе в роботі "Основи авторського права", В.М. Протасов у роботі «Теория права и Аержави. Проблеми теорії права і держави", В.П. Грибанов у книзі “ЗАійснення та захист авторських прав", О.П. Сергеєв у піАручнику "Авторське право", Є.О. Харитонов та А.І. Аришлюк у підручнику «Цивільне право України". Не можна забувати про роботи у сфері авторського права, які також важливі в юриспруАенції і які тією чи іншою мірою "торкаються" Ааної теми. Це такі автори, як: В.А. Бабенко та Н.Г. Оме^ян-Скирта, ^. Бентли та Б. Шерман, А.О. Бояр, Г.І. Миронюк та В.С. Ароб'язка, В.Я. Іонас, В.І. Торканюк, І.О. Панкеєв та ряд інших.

Метою досліАження $€$ визначення поняття способів реалізації суб'єктивного права на творчість та заійснення систематизації цих способів.

ВиклаА основного матеріалу. "Створювати (творити) - в широкому смислі цього слова - означає створювати дещо нове, тобто щось таке, чого раніше зовсім не було. Нове в такому його розумінні створює не тільки ^юдина, але і природа, а 
творчі зАібності ^юАини проявляються у створенні як Ауховних, так і матеріальних цінностей... творчість - це вже не будь-яка, а лише свідома творча Аіяльність, на яку зАатна мише ^юАина, а не стихійні сили природи. У той самий час не будь-який свіАомий акт творчості, зАійснений АюАиною, розгляАається як акт творчості" [1, с. 5].

Способом вважається певна Аія, прийом або система прийомів, яка дає можливість зАійснити що-небуАь, Аосягти чогось [7].

Яким чином можна реалізувати свої суб'єктивні права на творчість? Яким способом?

Реалізацією можна вважати втілення в Аію тих приписів та можливостей, що містяться в чинному законодавстві: Міжнародних актах, законодавстві України, підзаконних нормативно-правових Аокументах, судовій практиці тощо. Зазвичай особи втілюють такі можливості за Аопомогою суспільних відносин та своєї повеАінки, тобто реалізація неможлива без дії суб'єктів права та без наявності суспільства (та / або Аержави), з яким цей суб'єкт має або бажає мати взаємовідносини.

Ауже часто поняття "спосіб" ототожнюється з поняттям "форма" та "метоА" у цивільному праві.

Форма реалізації права - це зовнішнє оформлення змісту загальнообов'язкових правия повеАінки, які офіційно встановлені (санкціоновані) Аержавою або загальновизнані суспільством [8].

Методом взагалі можна вважати сукупність прийомів та засобів (способів) із Аосягнення поставленої цілі.

у різних галузях права існують свої способи реалізації його норм. У будь якому випадку, "оживити" норми права може тільки ^юАина, яка реалізовує ці норми в суспільно-вольовій діяльності.

Аотримання норми права - це форма реамізації забороняючих правових норм, яка полягає в утриманні суб'єкта віА активних Аій, в його пасивній поведінці, незалежно віА його волі. Тобто Аотримання норм права полягає в тому, що суб'єкти права узгоджують свою повеАінку з нормами-заборонами і не вчиняють Аій, які вважаються соціально шкіАливими чи небезпечними. Це, наприклаА, утримання віА Аій, які караються в порядку, встановленому законом.

Виконання норми права - це форма реалізації зобов'язуючих правових норм, яка полягає в активній повеАінці суб'єктів, що зАійснюється ними, як правило, незалежно від їхнього власного бажання. Виконання норми права - це, по суті, виконання ними своїх юридичних обов'язків, які вимагають активних Аій.
Використання норми права - це форма реалізації уповноважуючих правових норм, яка полягає в активній поведінці суб'єктів, яка зАійснюється ними за власним бажанням. Використання правової норми, на віАміну віА Авох інших форм реалізації, може бути тільки Аобровільним, тобто зАійснюватися викиючно за власним бажанням. Це, наприклаА, використання права власності тощо.

Застосування норми права - це особлива форма реалізації права, що включає поєАнання та співвіАношення Аотримання, виконання та використання. ЗАійснюється спеціально уповноваженими державними органами і посадовими особами. Має індивідуалізований, персоніфікований характер. Може засновуватись на будь-якому способі правового впливу залежно віА конкретної ситуації [9].

Але якщо сам процес реалізації вважати активним процесом Аіяльності АюАини, то Аотримання норм у процесі створення результату (твору) творчої діяльності можна вважати одним із інструментів, аАже "творець" зобов' язаний поважати авторські права інших осіб і не має права порушувати такі права, аАже за це може наступити певний виА віАповіАальності.

Виконання переплітається 3 Аотриманням, аАже виконання виходить із необхідності Аотримуватися певних норм і передбачає виконання обов'язку (наприклаА, обов'язок видавця подавати у встановленому порядку Аержавну статистичну звітність, інформацію про випущені у світ видання відповідно до а. 14 ст.20 Закону України "Про виАавничу справу").

Але наведені способи реалізації суб'єктивного права на творчість носять Аосить узагальнений характер і притаманні іншим видам правовіАносинам, що можуть виникнути в будь-якій галузі права. Нас цікавить специфіка способів реалізації саме права на творчість.

Ураховуючи визначення поняття "спосіб" та положення Цивільного Кодексу України та законодавства України, зокрема Закону України "Про авторське право і суміжні права", можна спробувати визначити способи, притаманні саме процесу реалізації суб'єктивного права на творчість.

«Реалізація, - відзначає В.М. Протасов, - преАставляється як процес перекладу явища в іншу якість, вживання його якостей, властивостей із метою Аосягнення якогось результату. ВіАносно права цей процес означає переклаА його норм в іншу реальність, в іншу якість - якість правомірної поведінки: використання властивостей права Аля Аосягнення необхіАного соціального результату" [2, с. 151]. 


\section{8 回回回回回回回回回回回回回回回回回回回回 Випуск 32}

ЗгіАно з нормами чинного законодавства громадяни і юридичні особи на свій розсуд зАійснюють належні їм цивільні права. Це означає, що всі питання, пов'язані з виконанням суб'єктивних прав, включаючи обсяг і засоби їх реалізації, а також вілмову віА суб'єктивних прав, передавання їх іншим особам та ін., вирішуються уповноваженою особою на свій розсуд. Іншими словами, зміст суб'єктивного цивільного права складають можливі дії уповноваженої особи. НаприклаА, автор книги може вимагати віА видавництва сплати належного йому гонорару.

Найбільш поширеним $€$ розпорядження громадянами і юридичними особами належними їм правами шляхом їх зАійснення. ПіА здійсненням права передбачається реалізація тих можмивостей, які надаються законом або договором в^аснику суб'єктивного права. Іншими словами, зАійснювати суб'єктивне цивільне право означає реально використати ту юридичну свободу, яка гарантується суб'єкту державою.

Вибір способу здійснення права залежить не тільки віА розсуду суб'єкта, але і віА конкретного змісту суб'єктивного права. Останнє, у свою чергу, визначається його призначенням, тобто тією метою, Аля якої воно наАається уповноваженій особі.

Реалізовуючи суб'єктивне право на творчість, особа обирає спосіб, характерний та актуальний саме Аля якогось конкретного твору, що є результатом реалізації такого права.

Аля виявлення найбільш характерних способів, притаманних процесу реалізації суб'єктивного права на творчість, можна розглянути всі можливі різновиди способів взагалі, що існують у системі реалізації суб'єктивних прав.

В.П. Грибанов у своїй роботі, яка стосується проблем зАійснення, наголосив на різниці між змістом та зАійсненням авторських прав: суб'єктивне право складає визначену міру можливої поведінки правомірної особи; здійснення суб'єктивного права - це реалізація таких можливостей [3, с. 43-45].

Багато науковців вважають, що способом зАійснення суб'єктивного права на творчість $€$ Аоговірна форма. За вираженням О.П. Сергєєва, "Аоговірна форма використання творів... більшою мірою, ніж будь-яка інша, забезпечує реалізацію і охорону як особистих, так і майнових прав автора" [4, с. 161].

Ознайомившись із роботами правознавців радянських часів та сучасних правознавців, я не побачила чіткого визначення способу реалізації суб'єктивного права на творчість, інше кажучи культурних прав. І Аійсно, Ауже часто про способи якось замовчується, а мова йде найчастіше про форми реалізації. Але і цю інформацію майже ніхто не висвітлює. Аеякі науковці надають інформацію про зАійснення творчих прав, піА чим найчастіше розуміють саме Аоговірну форму зАійснення авторських прав.

Проаналізувавши вищезазначене та інформацію, що міститься в законодавстві України, доцільним зАається виділити деякі виАи способів, якими особа може реалізувати суб'єктивне право на творчість:

1. Спосіб реалізації суб'єктивного права на творчість залежно віА необхідності застосування Аоговору:

1) Аоговірний спосіб - спосіб використання результату творчої Аіяльності особи, за якого необхідний Аозвіл творця (автора) чи особи, що має авторські права. “Використання об'єкта права інтелектуальної власності іншою особою, за загальним правилом, має зАійснюватися з Аозволу творця об'єкта інтелектуальної власності (уповноваженої ним особи, спадкоємців тощо)", за виключенням випадків, встановлених законодавством [5, с. 110]. ОАним із повноважень особи, яка має майнові права інтелектуальної власності, $є$ виключне право Аозволяти використання результату творчої Аіяльності іншими особами. Це право може бути реалізоване шляхом укладання ліцензійного Аоговору. У Ааний спосіб можна включити необхіАність укладення ліцензійного Аоговору.

Найпоширенішим видом авторського договору $€$ виАавничий Аоговір на мітературні твори, твори образотворчого мистецтва, на музичні твори, на видання перекладу раніше випущеного у світ мітературного твору; постановочний Аоговір; сценарний Аоговір; Аоговір художнього замовлення; Аоговір на використання в промисловості творів Аекоративно-приклаАного мистецтва; авторський Аоговір на створення і використання комп'ютерних програм;

2) неАоговірний - спосіб використання результату творчої Аіяльності особи, за якого віАсутня необхідність отримання Аозволу творця (автора) чи особи, що має авторські права. "Законом можуть бути передбачені випадки правомірного використання об'єктів інтелектуальної власності без такого Аозволу. Зокрема, ст. 444 ЦК переАбачає, що твір може вільно, без згоди автора чи інших осіб, безоплатно використати будь-яка особа як цитату з правомірно опублікованого 
твору або як ілюстрацію у виданнях, радіо- і телепередачах, фонограмах та відеограмах, призначених Аля навчання, за умови Аотримання звичаїв, зазначення Ажерела запозичення та імені автора, якщо воно вказане в такому Ажерелі, та в обсязі, виправданому поставленою метою; Аля відтворення в судовому та аАміністративному провадженні в обсязі, виправданому цією метою; тощо" [5, с. 110-111].

2. Спосіб реалізації суб'єктивного права на творчість залежно віА ступеня активності особи (автора, суб'єкта):

1) активний - такий спосіб реалізації суб'єктивного права на творчість, за якого особа зАійснює активні дії (написання твору, складає нову комп'ютерну програму тощо). Цей спосіб передбачає виконання та використання права, під час яких особа виконує свої юридичні обов'язки в процесі реалізації суб'єктивного права на творчість (наприклаА, необхідність отримання Аозволу на певні Аії або, наприклаА, обов'язок, встановлений авторським Аоговором замовлення, при якому автор зобов'язується створити в майбутньому твір віАповіАно Ао умов цього Аоговору і передати його замовникові; чи виконує активні Аії зі створення об'єкта інтелектуальної власності);

2) пасивний - спосіб реалізації суб'єктивного права на творчість, за якого особа утримується віА зАійснення активних чи буАь-яких інших Аій, за які встановлюється юридична віАповіАальність. У Ааному випадку виходить із форми (обов'язку) Аотримання. Суб'єкт повинен узгоджувати свою поведінку з нормами-заборонами: не робити того, що заборонено. Значення цієї форми реамізації норм права полягає в тому, щоб не Аопустити зАійснення Аій, які спричинили б шкоАу суспільству, Аержаві, окремій особі. Аотримання завжАи має пасивний характер. Реалізація цих норм Аосягається не в силу зАійснення активних Аій суб'єктами, а завАяки утриманню віА заборонених Аій. Таким прикладом може служити "споживчий" аспект реалізації суб'єктивного права на творчість. ААже існує Аумка, що реалізація суб'єктивного права на творчість передбачає не тільки створення, а й “споживання" готового результату творчої Аіяльності інших осіб Аля подальшого наробітку зАібностей і можливості створення нового об'єкту. Таку Аумку висловлює Т. Аткішкіна у своїй статті "Свобода творчості як форма реалізації суб'єктивного права у сфері культури": "Суб'єктивне право на культуру в широкому розумінні реалізується, з одного боку, як право художника на творчу свободу та ініціативу, втілення художньо-творчих проектів, а з Аругого - як право особистості, яка, так би мовити, є "споживачем", точніше - суб'єктом сприйняття творів мистецтва і культури [6, с. 126].

3. Спосіб реалізації суб'єктивного права на творчість залежно віА кількості суб'єктів:

1) самостійний (оАноосібний) - спосіб реалізації суб'єктивного права на творчість, за якого особа самостійно здійснює реалізацію суб'єктивного права на творчість, використовуючи свої творчі зАібності віАповідно до законодавства України;

2) колективний - спосіб реалізації суб'єктивного права на творчість, за якого особа приЄАнується чи Аозволяє приєАнатися Ао своєї творчої Аіяльності іншим особам. Регулюється, зокрема, Законом України «Про професійних творчих працівників та творчі спілки", Ае зазначено, що творчою спілкою є Аобровільне об'єАнання професійних творчих працівників віАповіАного фахового напряму в галузі культури та мистецтва, яке має фіксоване членство і діє на підставі статуту.

4. Спосіб реалізації суб'єктивного права на творчість залежно віА законності зАійснення та наявності необхіАних Аозволів у разі, якщо їх наявність вимагається законодавством:

1) ті, що потребують мегітимізації (Аозволу, міцензії тощо) - спосіб реалізації суб'єктивного права на творчість, за якого особа, що бажає реалізувати свої суб'єктивні права на творчість, зобов'язана провести процедуру отримання дозволів, встановлених законодавством України Аля віАповіАних напрямів творчої діяльності. Ао такого виАу можна вк^ючити ті способи реалізації суб'єктивних прав на творчість, за яких державою встановлена необхідність отримання ліцензії. Аіцензія на використання об'єкта права інтелектуальної власності - це письмове повноваження, видане особою, яка має виключне право Аозволяти використання об'єкта права інтелектуальної власності (^іцензіара), іншій особі (^іцензіату), яке надає їй право на використання цього об'єкта в певній обмеженій сфері;

2) ті, що не потребують легітимізації - спосіб реалізації суб'єктивного права на творчість, за якого особа, що бажає реалізувати свої суб'єктивні права на творчість, не має обов'язку проводити процеАуру отримання Аозволів або погоАження віА Аержави чи іншої особи, що має авторські права. При цьому особа може вільно розпоряджатися результатами своєї творчої діяльності віАповідно до законодавства України. 
Творча діяльність із правової точки зору завжди поєАнує в собі матеріальний і Ауховний світ автора, аАже якщо твір не АовеАений Ао віАома і віАомий тільки самому автору або залишається невтіленим, постає питання щодо захисту з боку законодавства. Тому можна завжАи говорити, що, зАійснюючи творчу Аіяльність, автор має в якості результату втілення своїх духовно-матеріальних потреб. Але, в будь-якому випаАку, автор має право втілювати свої "таланти" задля суспільства або особисто Аля себе (при цьому він не перестає бути автором). Таким чином, можна виАілити ще такі види способів реалізації суб'єктивного права на творчість, як:

1) за замовленням (Аля задоволення суспільних потреб) - такий спосіб реалізації суб'єктивного права на творчість, за якого особа, що має творчі заібності, втілює їх за попереднім замовменням віА інших фізичних та/або юридичних осіб. Такі твори стають соціально корисними;
2) особистий (А^я заАоволення особистих Ауховно-матеріальних потреб) - такий спосіб реалізації суб'єктивного права на творчість, за якого особа, що має творчі здібності, вті^ює їх тільки за наявності своїх (особистих) Ауховно-матеріальних потреб і не має на меті принести будь-яку соціальну користь. За такого способу реалізації суб'єктивного права на творчість твори, якщо і стають відомими, то зовсім випадково, коли розповсюАження набуває непередбаченої популярності.

Висновки. 3 огляду на викладену інформацію та аналіз точок зору вчених-правознавців, зроблено висновок, що спосіб реалізації суб'єктивного права на творчість - певна Аія, прийом або система прийомів, яка дає можливість особі реалізувати суб'єктивне право на творчість віАповіАно Ао норм законодавства, що встановлюють межі можливої поведінки суб'єктів.

\section{NITEPATYPA:}

1. Иоффе О.С. Основы авторского права. Авторское, изобретательское право, право на открытие : учебное пособие. Москва, 1969. $130 \mathrm{c}$.

2. Протасов В.Н. Теория права и государства. Проблемы теории права и государства. Вопросы и ответы. Москва : Новый Юрист, 1999. 240 с.

3. Грибанов В.П. Осуществление и защита авторских прав. Москва : «Статут», 2000. $411 \mathrm{c.}$

4. Сергеев А.П. Гражданское право : учебник. Москва : Проспект, 2000. 610 с.

5. Харитонов С.О., Дришлюк А.І. Цивільне право України. Суми, 2006. 352 с.

6. Аткішкіна Т. Свобода творчості як форма реалізації суб'єктивного права у сфері культури. Право та культура: теорія $i$ практика : матеріали міжнародної науково-практичної конференції. м. Київ. 15-16 травня 1997 р. Київ, 1997. 287 с.

7. Матеріал с вікісловника. URL : https://uk.wiktionary.org/wiki/\%D1\%81\%D0\%BF\%D0\%BE\%D1\%81\%D1\%96\%D0\%B1.

8. Форма права. URL : http://scicenter.online/teoriya-gosudarstva-prava-scicenter/forma-prava.html.

9. Форми реалізації права: поняття, види, співвідношення зі способами правового впливу. URL : https://studfiles.net/ preview/3009022/page:19/.

\section{Сабура Світлана Олександрівна \\ СПОСОБИ РЕААІЗАЦІї СУБЄКТИВНОГО ПРАВА НА ТВОРЧІСТЬ}

У статті розгляАається значення та розкриття поняття "спосіб" у контексті реалізації суб'єктивного права на творчість та наводяться ознаки відмінності від поняття "форма" та "метоА". Також проводиться систематизація існуючих способів реалізації суб'єктивного права на творчість, що дасть змогу в подальшому як іншим правознавцям піА час їхньої практичної діяльності швидко орієнтуватися у просторі юридичної інформації у процесі надання правових послуг, так і авторові піА час реалізації свого суб'єктивного права на творчість швидко захистити встановлену законодавством міру дозволеної поведінки особи.

Киючові слова: суб'єктивне право, форма, метоА, творчість.

\section{Сабура Светлана Александровна}

\section{СПОСОБЫ РЕААИЗАЦИИ СУБЪЕКТИВНОГО ПРАВА НА ТВОРЧЕСТВО}

В статье рассматривается значение и раскрывается понятие "способ" в контексте реализации субъективного права на творчество, и указываются отличительные признаки от понятий "форма" и "метод". Также проводится систематизация существующих способов реализации субъективного права на творчество, что позволит в Аальнейшем как Аругим правоведам при их практической деятельности быстро ориентироваться в пространстве юридической информации при предоставлении правовых услуг, так и автору при реализации своего субъективного права на творчество быстро защитить установленную законодательством меру дозволенного поведения мица.

Киючевые слова: субъективное право, форма, метод, творчество. 


\section{Sabura Svitlana}

\section{WAYS OF IMPLEMENTATION OF THE SUBJECTIVE RIGHT ON THE CREATION}

The article examines such important concepts as the method and form, which makes it possible to avoid mistakes when determining how to implement a subjective approach to creativity.

The article discusses the meaning and disclosure of the concept of the "way" in the context of the implementation of the subjective right to creativity and identifies the distinctive features from the concepts of "form" and "method". The article focuses on the opinion of legal scholars who provide information about the possible ways that a person uses in the process of exercising the subjective right to creation.

It also contains definitions of such important concepts as "compliance", "fulfillment", "use" of the rule of law, which allow a more detailed understanding of the variety of ways of realisation of the subjective right to creativity. To identify the most characteristic ways inherent in the process of implementing the subjective right to creativity, considered all of some of the varieties of methods in general, existing in the system of realization of subjective rights. The definition of such concepts as implementation, which provide an informative basis for the disclosure of a topic under the article, is given.

The importance of some forms of realization of the subjective right to creativity is revealed. Such a form can be considered a contractual form, because the contractual form provides for the implementation and protection of both the personal and property rights of the author.

It is established that in realizing the subjective right to creativity the person chooses the way characteristic and actual for a specific work that is the result of the realization of such a right.

Also, the existing options of exercising the subjective right to creativity are systematized, which will allow other lawyers in their practice to quickly navigate the legal information space in the provision of legal services, and the author, in exercising his subjective right to creativity, quickly protect the lawful measure of legal behavior faces.

Key words: subjective right, form, method, creativity. 